Between Elite Interests and Pro-Poor Resistance: The Nigerian Courts and Labour-led Anti-Fuel Price Hike Struggles (1999-2007)

Obiora Chinedu Okafor

Osgoode Hall Law School of York University, ookafor@osgoode.yorku.ca

Source Publication:

Journal of African Law. Volume 54, Number 1 (2010), p. 95-118.

Follow this and additional works at: https://digitalcommons.osgoode.yorku.ca/scholarly_works (c) (1) $(9)$

This work is licensed under a Creative Commons Attribution-Noncommercial-No Derivative Works 4.0 License.

Recommended Citation

Okafor, Obiora Chinedu. "Between Elite Interests and Pro-Poor Resistance: The Nigerian Courts and Labour-led Anti-Fuel Price Hike Struggles (1999-2007)." Journal of African Law 54.1 (2010): 95-118.

This Article is brought to you for free and open access by the Faculty Scholarship at Osgoode Digital Commons. It has been accepted for inclusion in Articles \& Book Chapters by an authorized administrator of Osgoode Digital Commons. 


\title{
Between Elite Interests and Pro-Poor Resistance: The Nigerian Courts and Labour-Led Anti-Fuel Price Hike Struggles (1999-2007)
}

\author{
Obiora Chinedu Okafor*
}

\begin{abstract}
Between 1999 and 2007, a popular Labour-led movement led a pro-poor struggle to resist the fuel price hike policy of the Nigerian government. Waged in the context of the poverty in which nearly 70 per cent of Nigerians lived, the operation of powerful incentives to raise fuel prices, and Labour's extraordinary socio-political leverage, these struggles triggered much government frustration. One of the strategies adopted by the government to legitimize its attempt to repress the movement was to resort to the courts. This article analyses, from a socio-legal perspective, the key cases relating to the validity of the government's attempts to repress the struggles. The article concludes that, although both pro- and anti-movement trends can be observed in the jurisprudence, the anti-movement tendency having so far prevailed in terms of formal legal precedent, the pro-movement (ie pro-poor) decisions have, as a result of their massive popular legitimacy, actually functioned as the "living law."
\end{abstract}

\section{INTRODUCTION}

The objective of this article is to map, analyse and contextualize the character and implications of the engagement of the Nigerian courts with the struggles for greater socio-economic equity, waged by a Labour-led movement (the Movement) against fuel price hikes during the period under study: an era in which Nigeria laboured under a form of quasi-democratic rule. ${ }^{1}$ What legal

Obiora Chinedu Okafor is a professor at the Osgoode Hall Law School, and faculty associate at both the Harriett Tubman Institute for the Study of the African Diaspora and the Centre for Refugee Studies - York University, Toronto, Canada. PhD, LLM (University of British Columbia, Vancouver, Canada); LLM, LLB (Hons) (University of Nigeria, Enugu Campus). The author is grateful to the Social Science and Humanities Research Council of Canada and York University for the generous funds that made this article possible. The author would like to thank Obiora Anozie, Chikeziri Igwe, Opeoluwa Ogundokun, Tony Caesar Okeke and Pius Okoronkwo for their excellent research assistance. The author is also grateful to Solomon Ukhuegbe for his painstaking commentary on a draft of this article.

$1 \quad$ PC Aka "Nigeria since May 1999: Understanding the paradox of civil rule and human rights violations under President Olusegun Obasanjo” (2003) San Diego International Law Journal 209 at 221. 
principles, doctrines, rules and logic were applied by the courts in the course of adjudicating the relevant cases, and how correctly or appropriately were they applied? How did the courts receive the Movement's anti-fuel price hike struggles (the Struggles) and the pro-poor resistance that they embodied? How did the relevant judges respond to the attempts by the executive branch of the Federal Government of Nigeria to use judicial decisions in their relentless efforts to outlaw (and thus suppress) the Struggles? How did the courts navigate the tensions created in this context by the clash between elite interests and pro-poor resistance? ${ }^{2}$

Although primarily driven by the unionized junior workers who associate under the banner of the Nigeria Labour Congress (the NLC), the Movement which prosecuted the Struggles was composed of a variety of civil society and grassroots organizations (including human rights non-governmental organizations, informal sector workers' associations, and many professional groups) ${ }^{3}$ and enjoyed very broad support among ordinary Nigerians. ${ }^{4}$ It was also remarkably unified, internally democratic, nationally spread and selffunded. ${ }^{5}$ Its most defining characteristic was its skilled focus on, and considerable success at, the mass mobilization of ordinary Nigerians, the vast majority of whom had been primed by decades of relative poverty and deprivation to receive favourably the Movement's anti fuel price hike message. ${ }^{6}$

On a methodological note, it should be noted that only three of the six known fuel pricing dispute cases decided by the Nigerian courts are examined in this article. However, as they are the main cases in the area, these three decisions suffice to tell adequately the story of the engagement of the courts with the Struggles during the period under study. On a related note, it is also important to point out that the analytical approach adopted is socio-legal; the cases analysed in this article are situated within their broader socio-economic and political context.

2 It should be noted, however, that the distinction made in this article between "elite" and "poor" Nigerians and between their respective "interests" is hardly of the binary (either / or) type. The two categories cannot be viewed as exclusive. On another note, the fact that other similarly situated judiciaries around the world do face and navigate similar challenges is illustrated by Balakrishnan Rajagopal's seminal article on the Indian Supreme Court: B Rajagopal "Pro-human rights and anti-poor? A critical evaluation of the Indian Supreme Court from a social movement perspective” (2007) April-June Human Rights Review 157.

3 "Fuel price hike: NANS plans nation-wide protest" (2 September 2005) Daily Champion, available at: <http://allafrica.com/stories/200509020028.html> (last accessed 23 September 2005).

4 For example, see ER Aiyede "United we stand: Labour unions and human rights in the democratisation process in Nigeria" (2004) 14 Development in Practice 224 at 229-30; and TE Turner and LS Brownhill "Why women are at war with Chevron: Nigerian subsistence struggles against the international oil industry" (2004) 39 Journal of Asian and African Studies 63 at 74.

5 OC Okafor "What should African human rights activism become?" (forthcoming)

6 Turner and Brownhill "Why women are at war", above at note 4. 
This introduction is followed by an explanation of the socio-economic and political context in which the engagement of the Nigerian courts with the Struggles occurred. The third and most extensive section of the article is then devoted to analysing the sampled cases. Building on that detailed analytical exposé, the next section offers a brief overarching assessment of the behaviour of the Nigerian courts under pressure from both the powerful protagonists of the elite's interests and the highly popular purveyors of propoor resistance. The last section summarizes the article and offers a conclusion.

\section{THE SOCIO-ECONOMIC AND POLITICAL CONTEXT}

The character and implications of the engagement of the courts, during the period under study, with the Movement's Struggles cannot be adequately understood without an appreciation of the socio-economic and political context. This section therefore outlines the main characteristics of the relevant context.

One of the defining features of Nigerian socio-economic and political life during the period under study was the intense contestation that occurred over key aspects of the economic reform measures pursued by the Obasanjo government. Despite that government's claims to have introduced a "home grown" economic reform package into Nigeria, it in reality espoused and implemented a set of key reform policies that mostly re-iterated the main elements of the structural adjustment policies (SAPs) that had characterized the economic programmes of virtually every Nigerian government since the mid-1980s. ${ }^{7}$ One such element, the policy of fuel price increases with which this article is concerned, has a long pedigree in Nigeria. ${ }^{8}$ For instance, between 1985 and 1993, the Babangida regime introduced an almost identical policy under its "home grown" (read SAP) reform programmes. ${ }^{9}$

Furthermore, it is important to note that all the fuel price hike (and other such) policies implemented from the mid-1980s to the end of the Obasanjo regime were either inspired or supported by the International Monetary Fund (IMF) (and, to a lesser extent, the World Bank). ${ }^{10}$ As is well recognized

7 OC Okafor “The precarious place of Labour rights and movements in Nigeria's dual economic and political transition 1999-2005" (2007) 51 Journal of African Law 68 at 74-78; and O Obasanjo "Briefing to the National Assembly on the report of the national political reform conference and recent debt relief granted to Nigeria” (26 July 2005), available at <http://www.dawodu.com/obas42.htm> (last accessed 3 October 2005).

8 Id, Okafor at 76 and 80.

9 P Lewis "From prebendalism to predation: The political economy of decline in Nigeria" (1996) 34 The Journal of Modern African Studies 79 at 80 and 82-85; P Mosley "Policy-making without facts: A note on the assessment of structural adjustment policies in Nigeria, 1985-1990" (1992) 91 African Affairs 227 at 228-30; and JO Ihonvbere "Economic crisis, structural adjustment and social crisis in Nigeria” (1993) 21 World Development 141 at 143.

10 For example, see: P Mosley, ibid; S Amadi "Contextualizing NEEDS: Political and economic development" in S Amadi and F Ogwo (eds) Contextualizing NEEDS: 
by observers of the Nigerian socio-economic scene, the IMF and World Bank support for the policy of fuel price increases has, because of the ways in which these increases have highly accentuated the impoverishment of average Nigerians, been highly unpopular. ${ }^{11}$ The unpopularity of this policy among the vast majority of Nigerians has remained constant, notwithstanding the shifts and changes which have occurred in government. ${ }^{12}$ Virtually every fuel price hike that was announced by the government has been massively unpopular and has in almost all cases been resisted by most Nigerians. ${ }^{13}$

The massive uproars that such fuel price hikes have occasioned in the specific Nigerian context may be impossible to understand without a close appreciation of the socio-economic significance of the cost of fuel in that country. Nigeria is the sixth largest producer of petroleum in the world; although over 70 per cent of the population are poor, decent public transport is still either unattractive, unaffordable, inefficient and / or unavailable; public transportation is almost all owned and dominated by profiteering private operators; steep inflation in the price of food and other essential commodities (often resulting from increases in the costs of transportation) is rampant; and the costs of doing business are easily and devastatingly increased by high fuel costs. The cost of fuel is therefore a highly significant indicator of socioeconomic well-being (or, more accurately, the lack thereof). Nigeria's poor majority and people with fixed incomes (such as unionized workers) are particularly affected by the negative impact of high fuel costs.

Yet, despite the widespread unpopularity of the fuel price hikes implemented during the 1999-2007 period by the Obasanjo government, the partisan political class (as represented by ruling and opposition party members) showed little leadership of their own in resisting these price hikes. For one, during this period the Nigerian political scene was, for good or ill, heavily dominated by the ruling Peoples Democratic Party, forcing the opposition to the outermost margins of real political power. ${ }^{14}$ This reality inhibited the opposition's ability to challenge effectively relevant government policies. This did not mean, however, that the partisan political class expressed no opposition whatsoever to the government's fuel price hikes. ${ }^{15}$ Even ruling

contd

Economic / Political Reform in Nigeria (2004, Human Rights Law Service and Centre for Public Policy and Research) at 13; IMF "Nigeria: 2005 article IV consultation" in IMF Country Report No 05/302 (25 March 2005, IMF) at para 58; and IMF "Semi-annual staff report under intensified surveillance: Nigeria, 2004" in IMF Country Report No 05/37 (February 2005, IMF) at 2, 9-10, 12 and 22.

11 JO Ihonvbere "Economic crisis", above at note 9 at 47; and OC Okafor "The precarious place," above at note 7 at $79-84$.

12 Ibid.

13 Ibid.

14 International Crisis Group "Nigeria: Failed elections, failing state?" in Africa Report No 126 (30 May 2007, International Crisis Group) (on file with the author).

15 National Assembly Debates (House of Representatives) (vol 1, no 34, 2003) (on file with the author) at 1064; National Assembly Debates (House of Representatives) (vol 1, no 40, 2003) 
party legislators tended either to condemn openly or oppose more quietly such price increases. ${ }^{16}$ Yet, it is fair to say that, during this period, a kind of leadership vacuum characterized this particular area of Nigeria's national life.

This resistance vacuum was filled to a large extent by the Labour-led Movement. ${ }^{17}$ Drawing on Labour's very long tradition of broader socioeconomic and political struggle in Nigeria, ${ }^{18}$ the Movement succeeded in mobilizing the vast majority of ordinary Nigerians against the government's fuel price hikes. On virtually all of the numerous occasions on which the government increased fuel prices, the Movement was able to mobilize very large numbers of Nigerians to express their opposition to these increases. ${ }^{19}$ As a result, the Movement was so effective at resisting and impeding the government's fuel price hikes that then President Obasanjo once identified them in a national broadcast as the main obstacle to the implementation of his government's fuel price hikes. In his own words, "the result [of the Movement's Struggles] has been that we took too little steps to achieve no meaningful and satisfactory progress [in implementing the government's fuel pricing policy]." 20

The government's frustration at the Movement's consistent obstruction of its ability to implement fuel price hikes was so intense that, in the same broadcast, Obasanjo angrily expressed "deep concern over the conduct of the Nigeria Labour Congress", the driving force of the Movement, and forcefully indicated his "Government's resolve to ensure that the ongoing reform agenda remains on course". ${ }^{21} \mathrm{He}$ also referred to the NLC leadership's efforts to resist his government's fuel price hikes as "irresponsible" and went on to accuse them of attempting to run a "parallel government". ${ }^{22}$ The government's high level of frustration was heightened further by the great pressure that was mounted on it in the other direction by a number of other factors, including a troubled

contd

(on file with the author) at 1243; Report of the Meeting Held by the Senate Committee on Employment, Labour and Productivity with Stakeholders on the Recent Increases in the Pump Prices of Petroleum Products and the Threat of a Nationwide Strike by [the] NLC and Civil Society Groups (October 2004) (on file with the author) at 6; and P Nwaigwe "Fuel hike: Reps move to empower NLC" at 4, available at: <http://news.biafranigeriaworld.com /archive/2004/oct/01/092.html> (last accessed 23 April 2008).

16 Ibid: Nwaigwe.

17 Okafor "The precarious Place", above at note 7 at 79-84.

18 Regarding Labour's long tradition of broader social struggle, see: A Abimbola "Pressure groups and the democratic process in Nigeria (1979-1993)" (2002) Nordic Journal of African Studies 38 at 40-41; and Aiyede "United we stand", above at note 4 at 225-26.

19 Ibid. See also "Streets empty for Nigerian strike" (21 June 2007) BBC News, available at: < http:// newsvote.bbc.co.uk/mpapps / pagetools/print/news.bbc.co.uk/2/hi/africa/6225694.stm> (last accessed 21 June 2007).

20 O Obasanjo "Text of a national broadcast" (8 October 2003) at 2, available at: < http:// www.dawodu.com/obas17.htm> (last accessed 20 June 2008).

21 Id at 1.

22 Id at 2-3. 
Nigerian economy, a failing petroleum refinery system that needed massive fresh investment to sustain it, sporadic shortages of fuel, the IMF and World Bank, and the rich creditor states and their trans-national corporations. ${ }^{23}$ These actors and factors relentlessly pushed the government to "raise fuel prices to 'international [and therefore more profitable] levels"”. ${ }^{24}$

The government's intense frustration, combined with the great pressure it was put under from these other opposing actors and factors, precipitated the strident efforts on its part to repress the Movement. Limited by its semi-democratic character in the extent of violence it could deploy, the government introduced a harsh bill to the National Assembly proposing the enactment of a statute that would, among other things, hinder the NLC's ability to unify Nigeria's Labour unions (the main drivers of the Movement) and ban labour strikes altogether; this bill is discussed much more extensively in two other full-length papers. ${ }^{25}$ In addition, the government filed a number of cases in the courts with the express objective of getting the courts to outlaw the Movement's anti-fuel price hike protests. ${ }^{26}$

Quite apart from this extended government / Movement contest over fuel price hikes, the other relevant major feature of the specific socio-economic and political context within which the cases discussed in this article were decided is that, not being strangers to Labour-led broader social struggles, the Nigerian political scene was quite accepting of the legitimacy of Labour's role. First, as suggested above, Nigerian Labour has a long tradition of waging such struggles, dating back as far as the colonial era. ${ }^{27}$ Over time, Labour and its allies have struggled not just against fuel price hikes, but also in favour of a host of broader social values, including fair elections and democracy, and greater transparency in governance. ${ }^{28}$ That virtually all Nigerian governments have, in practice, tended to accept the legitimacy of Labour playing this broader social role is underscored by the fact that various governments over the years have almost always negotiated with Labour in respect of these issues. ${ }^{29}$

23 Okafor "The precarious Place", above at note 7 at 79-80.

24 Ibid.

25 Id at 78-89; and OC Okafor "Remarkable returns: On the influence of a Labour-led socioeconomic rights movement on legislative reasoning, process and action in Nigeria (1999-2007)" (2009) 49 Journal of Modern African Studies (in press).

26 Ibid.

27 A Abimbola "Pressure groups and the democratic process", above at note 18 at 40-41; and ER Aiyede "United we stand", above at note 4 at 225-26.

28 "Sit-at-home strike holds nationwide" (29 May 2007) The Guardian, available at: <http://www. guradiannewsngr.com/news/article02> (last accessed 29 May 2007); "Refineries mess: Transcorp mafia angry with Yar'Adua" (22 July 2007) The Daily Sun, available at: <http:// www.sunnewsonline.com/webpages/features/powergame/2007/july/22/powergame-22-> (last accessed 22 July 2007).

29 "Why we called off strike - Labour" (24 June 2007) The Punch, available at: <http://www. punchontheweb.com/Articl.aspx?theartic+Art2007062418294562> (last accessed 24 June 2007). 
It was within this social context that the relevant courts examined the sensitive question of the legality of the Movement's Struggles. It is also against this background that the validity and appropriateness of the judicial decisions that are discussed in this article must be assessed.

\section{THE NIGERIAN COURTS AND LABOUR-LED ANTI-FUEL PRICE HIKE STRUGGLES}

A representative sample of the judicial decisions that tell the story of the engagement of the Nigerian courts with the Struggles are discussed in this section. These judicial decisions are discussed under two main sub-headings: the pro-government cases; and the pro-Movement case. Other than merely examining the soundness of their doctrinal legal reasoning, the article also attempts to situate each case in its socio-economic and political context.

\section{The pro-government cases}

The Ukeje decision ${ }^{30}$

On 6 February 2004, the government filed a suit at the Federal High Court in Abuja (Nigeria's administrative capital), seeking a number of declarations and injunctions against the NLC and its president, Adams Oshiomhole. The resulting judgment was so potentially consequential and caused so much controversy in the country that, although it was eventually appealed, the complicated story of the engagement during the period under study between the courts and the Movement cannot be told effectively without a detailed discussion of this case.

Put simply, the government's main request to the court was that it should declare it illegal for the NLC to embark on a strike over the central Labour organization's opposition to the government's fuel price hikes. The basis for the government's request was its view that such strikes could not be "in contemplation or furtherance of a trade dispute, as provided for under the Trade Disputes Act", and that only genuine trade disputes can ground a lawful strike. ${ }^{31}$ The government also asked the court to declare that the president of the NLC cannot as such lawfully "induce any worker or employee in Nigeria to embark on any [anti-fuel price hike] strike action". ${ }^{32}$ As suggested by both the above discussion and a motion on notice which the government later filed in the same court, ${ }^{33}$ the government's real objective was not simply to prevent the NLC from undertaking strikes in the strict sense of the term, but to prohibit the NLC and its allies in the Movement from mobilizing the

30 Federal Government of Nigeria and Another $v$ Adams Oshiomhole and Another, suit no FHC/ABJ/CS/52/2004 (21 September 2004) Federal High Court, Abuja, per Roseline Ukeje CJ (certified true copy on file with the author).

31 Id at $1-2$.

32 Id at 2.

33 Ibid. 
members of the NLC's 29 constituent unions and other Nigerians to engage in the usually effective anti-fuel price hike mass actions that the NLC often organized. The alleged basis of the government's claim was that such mass actions were not really "trade disputes" within the meaning of the Trade Disputes Act. ${ }^{34}$ Specifically, although later withdrawn, ${ }^{35}$ the motion on notice sought an order of the court, akin to that sought in the main case: "Restraining the Defendants [the NLC and its president] by themselves or [their] agents from embarking and / or continuing any strike or mass protest, assembly or rally or any other form or manner of physical protest on account of the N1.50 k Price Modulation of PMS and AGO [ie fuel] Policy ... [of the government]". ${ }^{36}$

For its part, the NLC and its president argued in the documents filed in court and in the president's testimony that, since the government's fuel price increases effectively reduced the earnings of most average Nigerians (including the workers who compose the NLC), through the imposition of significant additional transport and other costs, these Nigerians were entitled to protest against these hikes under the aegis of the Movement. ${ }^{37}$ They further contended that the right of workers to protest "is not limited to the "world of work' alone". ${ }^{38}$ They cited section 40 of Nigeria's Constitution of 1999 (the Constitution) to support this argument. ${ }^{39}$ What is more, as articulated in the following extract from then NLC President Oshiomhole's testimony in this case, the Movement maintained that "a trade union is an association of workers to regulate its relations with its employers, among other aims ... [and that] it is the duty of civil society to monitor the workings of government". ${ }^{40}$

For present purposes, four main questions were either formulated by the court for determination in this case, or implied in its reasoning. It is on these four questions that the remainder of the analysis of this case focuses.

(1) Are fuel price hike disagreements "trade disputes", thus entitling the NLC to prosecute strikes over them? With regard to this first major issue, the court noted that both section 47 of the Trade Disputes Act and section 52 of the Trade Unions Act ${ }^{41}$ define a trade dispute in exactly the same way, as "any dispute between employers and workers or between workers and workers, which is connected with the employment or non-employment or terms of employment and physical conditions of work of any person". ${ }^{42}$ Thereafter, the court reasoned that, for a dispute to qualify as a trade dispute, it must flow from the employment of the workers who compose the relevant union. ${ }^{43}$

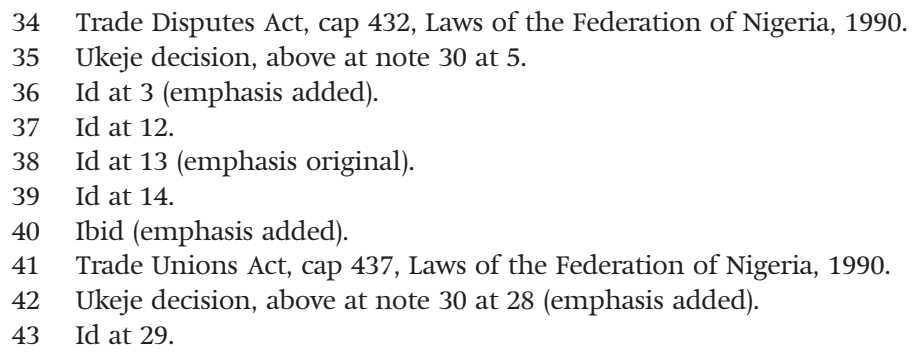


The court then argued that, as such, a fuel price hike dispute between the government and the NLC is not a trade dispute within the meaning of these two statutes. ${ }^{44}$

While the court's reasoning here appears plausible at first, it does not withstand analysis. Aside from the fallacy of the obvious narrowness of the court's construction of the expression "connected with" within the definition of "trade disputes" discussed above, the key contrary argument is that since, under the Constitution, every citizen is guaranteed certain legally enforceable human rights, ${ }^{45}$ the enjoyment of those inalienable and supreme rights must be viewed as an implied term in the contract of employment of each and every worker in Nigeria, wherever and for whomsoever he or she may work. Similarly, since Nigeria's African Charter on Human and Peoples' Rights (Ratification and Enforcement) Act (the African Charter Act) ${ }^{46}$ statutorily guarantees an even more extensive list of human rights to all Nigerians, the enjoyment of the rights specified in that statute must also be read into the terms of employment of all Nigerian workers. For example, how can any employer in Nigeria credibly claim that, in the absence of explicit reference within the relevant contract of employment, it is not required to guarantee freedom from slavery and servitude for its workers? What is more, being as Nigerian as anyone else, the members of the NLC's constituent trade unions cannot, of course, be excluded from the enjoyment of any of the human rights guaranteed under either the Constitution or the African Charter Act. This last point is supported by the strong human rights mandate imposed on the NLC by its own articles of association, ie its constitution. ${ }^{47}$ As such, to the extent that fuel price hikes seriously impair any of the human rights guaranteed under these two documents, such as access to the right to freedom of movement under the Constitution, or access to the explicit or implied rights to education, housing, or health under the African Charter Act, ${ }^{48}$ fuel price hikes

44 Id at 30-32.

45 Constitution of Nigeria 1999, available at: < http://www.nigeria-law.org/Constitution OfTheFederalRepublicOfNigeria.htm $>$ (last accessed 5 July 2008).

46 Cap 10, Laws of the Federation of Nigeria, 1990. This domestic statute incorporates and domesticates the African Charter on Human and Peoples' Rights into Nigeria's internal law and reproduces the text of that treaty. See the African Charter on Human and Peoples' Rights (1982) 58 ILM 21 (the African Charter).

47 As discussed in the next sub-section of this article, art 3 of the NLC's constitution clearly mandates the NLC to "protect, defend and promote the rights, well-being and the interests of all workers" in the "work-place and society" and protect to "pensioners" in similar ways. As important, the same provision also charges the NLC in general terms to "promote and defend trade union and human rights, the rule of law and democratic governance". What is more, this portion of the NLC's constitution is incorporated by reference into sec 34(1)(e) of the Trade Disputes Act. As such, it is one of the statutory functions of the NLC to defend the human rights of its workers.

48 Arts 16 and 17 of the African Charter guarantee the rights to health and education respectively. The African Commission on Human and Peoples' Rights (the African Commission) has inferred that a number of provisions of the African Charter protect 
could reasonably be viewed as matters that are "connected with" the terms of employment of the relevant workers and therefore as capable of grounding lawful strikes. ${ }^{49}$

It is for all these reasons that the court's rather superficial reasoning regarding this question is unconvincing. Too many plausible alternative arguments were left either under-explored or unexplored altogether.

(2) Can the NLC declare a strike in its own name? With regard to this second issue, the court reasoned that: since section 34 of the Trade Unions Act does not explicitly state that the NLC is authorized to "engage itself in any negotiation between a specific union and its employers; [since that statute] states that the NLC can only do so at the request of the particular Trade Union" involved; and given the fact that section 34(2) and (3) of the same act bars the NLC from doing so on pain of its officials (and itself) being found guilty of an offence, the NLC (in and of itself) "has no power under the law" to declare any kind of strike at all, let alone a strike over fuel prices. ${ }^{50}$ To this end, the court held that: "Consequently, where the Nigeria Labour Congress or $\mathrm{Mr}$ Oshiomhole [the then president of that organization] acts to call workers out on strike, they act outside the provisions of section 34(1) and incur the penalty imposed by section 34(2) and (3) of the Trade Unions Act (cap 437)".51

In the view of the court, only the individual trade unions which constitute the NLC could declare strikes. According to this view, general strikes declared by the NLC in its own name are illegal and unconstitutional.

Most striking and disappointing in this connection, the court misdirected itself in law by failing to pursue the obvious logic set out in section 34(1)(e) of the Trade Unions Act, a provision on which it relied heavily and which is reproduced in its judgment. ${ }^{52}$ Section 34(1)(e) provides that the NLC "shall have power, subject to its rules", to undertake a number of activities,

contd

the right to housing. According to the African Commission, "[a]lthough, the right to housing or shelter is not explicitly provided for under the African Charter ... it is thus noted that the combined effect of Articles 14, 16 and 18(1) reads into the Charter a right to shelter or housing which the Nigerian Government has apparently violated": Social and Economic Rights Action Centre and Another v Nigeria, comm no 155/96, reproduced in Fifteenth Annual Activity Report of the African Commission, 2001-02 (on file with the author) at para 60 .

49 This is so despite Okene's argument that in the first place, as a matter of law, there is no positively framed right to strike in Nigeria. This article is not concerned with that particular question. It is concerned with whether a fuel price hike dispute can ever ground a lawful strike in Nigeria, even when the right to strike itself is implied and not explicitly stated: OVC Okene "The status of the right to strike in Nigeria: A perspective from international and comparative law" (2007) 15 African Journal of International and Comparative Law 29 at $40-43$.

50 Ukeje decision, above at note 30 at 27.

51 Ibid.

52 Id at 24 . 
including the power to "render any other assistance provided for under the [NLC's] articles of association". Faced with this provision, the only reasonable thing for a court to have done was to seek out the NLC's constitution (ie its articles of association) and explore what other forms of assistance that document allows the NLC to render to its members (ie what other implied statutory functions the NLC is mandated to perform). Yet, almost inexplicably, the court did not do so. Had it followed this rather obvious path, and not ignored the NLC's constitution, the court would have easily discovered that, as discussed above, article 3 of the NLC's constitution clearly mandates the NLC, inter alia, to "promote and defend trade union and human rights, the rule of law and democratic governance". As such, one of the NLC's functions under the very section 34(1) of the Trade Unions Act on which the court relied in order to reach a particular conclusion is the defence of human rights. It follows therefore that, at the very least, the NLC itself can lawfully declare and prosecute a strike (or at a minimum undertake other protest action) in a bid to defend the human rights of its members (rights that, as has been shown, ought to be regarded as implied terms in the contracts of employment of its members). As the government's fuel price hikes significantly impaired the enjoyment of the human rights of its members, the NLC could, under the law and in its own name, declare and prosecute a strike (or at the very least a mass protest) over such fuel pricing disputes.

What is more, as one commentator has noted, the court misconstrued the provisions of sections 34(2) and (3) of the Trade Unions Act which bar the NLC from intervening in trade dispute negotiations on behalf of any of its constituent unions, save with the express permission of that union..$^{53}$ This provision clearly permits such a union, if it so chooses, to authorize the NLC so to intervene. This provision is merely meant to prevent the NLC from interfering in such negotiations when the relevant union does not so consent.

In any case, what exactly in section 34 of the Trade Unions Act (or any other act for that matter) prohibits the trade unions which compose the NLC from simultaneously requesting their central body to bargain with their employers on their behalf and, if necessary, agree to proceed on a strike in a coordinated fashion? ${ }^{54}$

Based on these arguments, it is only reasonable to conclude that the court's reasoning with regard to this particular question is rather unconvincing.

(3) Can the NLC and its allies undertake anti-fuel price hike mass action campaigns? With regard to this question (one that is more or less implied in the judgment), the court's precise views are harder to decipher. Too much of the court's judgment inappropriately conflates issues, making it hard to isolate its reasoning on any one particular issue. However, the court seemed to

53 E Adegboruwa "Court verdict on NLC and strike: Where Justice Ukeje erred" at 6, available at: <http://www.dawodu.com/adegboruwa1.htm> (last accessed 23 September 2005).

54 NLC Constitution, art 8. 
suggest, without directly addressing the point in any detail, that, as a confederation of trade unions, the NLC can only exercise its broader constitutionally guaranteed protest rights in relation to issues or concerns which relate to or flow from "employment". In the words of Justice Ukeje, "although the defendants have fundamental rights guaranteed under section 40 of the Constitution, that right is not at large. It must relate or flow from an employment". ${ }^{55}$ As such, in the court's view, since the fuel pricing issue does not relate to or flow from employment, the NLC cannot lawfully launch a mass action that involves non-members of that body over that issue. Thus, in effect, the court reduced the NLC membership's enjoyment of the general protest rights (derived from their rights to freedom of assembly / association and expression under sections 40 and 39 of the Constitution) to a much denuded and far less potent circumscribed right to protest only over employment issues.

Were this line of reasoning to be correct, the result would be patently absurd. The Nigerian citizens who compose the NLC and whose rights are supposed to be strengthened when they join any of the affiliate unions of the NLC (since they, unlike most Nigerians, would then acquire the statutory right to strike), end up experiencing a reduction in, rather than enlargement of, their rights. They, in effect, lose rights as a result of their unionization. Their constitutional rights become limited in a way that the constitutional rights of other Nigerians (who have not joined any of the NLC's affiliated unions) are not. In effect, unionized Nigerians would enjoy fewer constitutional rights than other citizens. Surely, this cannot be the intention of the drafters of the Constitution.

The court's reasoning would have been somewhat more plausible (though still not valid) had it explicitly limited itself to stating that the exercise of trade union rights (as opposed to all of the fundamental rights) guaranteed as part of section 40 must be limited to the employment context.

In any case, a key criticism that can be made of this aspect of the Ukeje decision is that, in treating the NLC's right to strike over trade disputes as virtually co-extensive with its right to launch mass protests against the government, the court misdirected itself both in fact and law. In terms of the court's factual (and conceptual) mistake in this regard, the key point is that, however much the two practices often overlap in the Nigerian context, mass actions may or may not encompass strikes. ${ }^{56}$ This distinction is important because an entity or person may be entitled to prosecute a mass action without being permitted by the law to undertake a strike.

With regard to the way in which the court was mistaken in law, as suggested above, sections 39 and 40 of the Constitution recognize the rights of any person or group of persons to freedom of expression and freedom of

55 Ukeje decision, above at note 30 at 32 (emphasis added).

56 "Nigerian march against fuel hikes" (14 September 2005) BBC News, available at: <http:// news.bbc.co.uk/2/hi/africa/4244556.stm> (last accessed 3 October 2005). 
assembly / association respectively. At the very least, these rights clearly entail and imply the broad right to protest peacefully against any and every government policy of which those persons disapprove. Article 9 (freedom of expression), article 10 (freedom of association) and article 11 (freedom of assembly) of the African Charter (and of course Nigeria's African Charter Act) protect these same rights. Article 19 (freedom of expression), article 21 (freedom of assembly) and article 22 (freedom of association) of the International Covenant on Civil and Political Rights (ICCPR) contain similar guarantees. It is, of course, important to point out that the enjoyment of these rights is limited by the extent to which they are derogable in times of public emergencies that threaten the life of a nation (such as under article 4 of the ICCPR), or by exceptions which are strictly necessary in the interests of national security, public safety or public order, and so on, as provided for in some of the relevant instruments. Yet, it is clearly not permissible under these exceptions, as the court did, to prohibit indefinitely all forms of mass action launched by the NLC or any other group just because they seek to protest against fuel price hikes. As such, quite apart from the merits of the NLC's right to launch strikes, it is inconceivable that the NLC is, under either constitutional or international law, without a broad right to prosecute mass actions against the fuel pricing policies of the Nigerian government. Thus, in barring the NLC, not just from undertaking strikes (strictly so called) over fuel price hikes, but also from launching mass actions over that issue, the court considerably overreached the boundaries set by domestic and international law.

(4) Can the NLC coerce non-members to join its mass actions, or can it persuade them to do so? With regard to the last major issue, whether the NLC and its allies in the Movement can coerce non-members to join its mass actions, and the intimately related issue of whether that organization can persuade ordinary Nigerians to participate in such campaigns, the court held (correctly in the author's view) that "it is not any [sic] fundamental right of the Defendants [the NLC] to force persons, not members of their union, to join their protests and strikes. Such strikes may not protect the interest[s] of such non-union Nigerians". ${ }^{57}$ Elsewhere in its judgment, the court also held that such coercion to participate in mass actions breaches the fundamental rights of those non-members of the NLC who experience it. ${ }^{58}$ Clearly, it would be unlawful and inappropriate to force any person, against her or his will, to participate in a mass action organized by the Movement. Therefore, framed as it was, this portion of the court's judgment is virtually unassailable.

However, it is rather troubling that the court neither explicitly raised nor directed its mind to any significant extent to the related question of the NLC's legal entitlement to persuade (rather than coerce) non-members to join its mass actions. Instead the court declared rather tersely at least once in its judgment that, if a strike (as opposed to a mass action) is called by any

57 Ukeje decision, above at note 30 at 31 (emphasis added).

58 Id at 39. 
trade union, only members of that union and their employers can be involved in that strike. ${ }^{59}$ The implication here is that neither the affiliate unions of the NLC nor the NLC itself (assuming it can even call a strike in its own name) may persuade non-members to participate in its strikes. Whatever the validity of this line of reasoning in relation to the NLC's ability to undertake strikes (strictly so-called), this logic in no way addresses the more important question of the NLC's legal entitlement to persuade non-members to participate in one of its mass actions. Clearly, if as has been shown already nothing under Nigerian law prevents the NLC from prosecuting a peaceful mass action, then it is also the case that nothing prohibits it from persuading other Nigerians to support and participate in that protest action. To hold otherwise would be to restrict inappropriately the freedom of assembly / association and freedom of expression rights of the members and non-members of the NLC alike. This specific point was not addressed to any significant extent in the court's judgment.

Ukeje: Between elite interests and pro-poor resistance? The (de)merits of the doctrinal logic espoused in the court's judgment aside, the fact remains that, whether or not the court so intended, its decision in this case provided a significant (albeit limited) political boost to the implementation of the government's fuel price hike policy: a policy that was as hugely unpopular as it was anti-poor in at least its effects. ${ }^{60}$ The Ukeje decision did provide considerable comfort and succour to the government and the tiny minority of Nigerians who support its fuel pricing policies. It is beyond reasonable dispute that the government filed this case in the hope of placing a significant obstacle in the path of a movement that had for so long resisted effectively its fuel pricing policies. It is also incontrovertible that hampering the Movement's resistance efforts in this way was meant to facilitate the government's ability to implement its policy. It only follows that, since the Movement's ability to mobilize millions of Nigerians to express disagreement with or protest against the government's fuel pricing policy was the main obstacle to its implementation, the judicial neutralization of that ability would help clear the way for the implementation of the policy. Not surprisingly, barely two days after the Ukeje decision was handed down, the government felt able to raise fuel prices, something which it had not been able to do for quite some time before. ${ }^{61}$

59 Ibid.

60 For examples of scholarship and commentary establishing the anti-poor character and unpopularity of such policies, see: P Mosley "Policy-making without facts", above at note 9; JO Ihonvbere "Economic crisis", above at note 9 at 143; S Olukoya "Nigeria's gas crisis: Suffering in the midst of plenty" (14 May 2001) CorpWatch (on file with the author); "The views of Mazi Sam Ohuabunwa, the president of the Nigerian Employers Consultative Association" (13 June 2007) The Vanguard at 1; and the views of the Nigerian government acknowledging the impact of "the price levels [of fuel] on the economy and social life and livelihood of Nigerians" in (24 June 2007) Daily Champion at 1. 


\section{The Odili decision 62}

This case was an appeal from the Ukeje decision discussed above. Dissatisfied with the Ukeje decision, the NLC approached the Abuja division of the Court of Appeal of Nigeria requesting it to set aside the lower court's judgment. The six issues for determination proposed by counsel for the NLC were adopted by the court. ${ }^{63}$ Overall, these issues can be subsumed under the same four questions discussed in relation to the Ukeje decision. As might be expected, the arguments which both sides made before the Court of Appeal did not depart significantly from the positions that the parties espoused in the lower court. It is therefore unnecessary to repeat those arguments here. It suffices to proceed directly to an analysis of the appellate court's decision. Yet, given the similarities in the reasoning of both the lower court and the appellate court, and the extensive discussion and critique of that reasoning offered in the last section, the discussion and analysis here is brief.

Regarding the question whether fuel price hike disputes are indeed "trade disputes", thus entitling workers to prosecute strikes over them, the court reasoned that, for a dispute to qualify as a "trade dispute" within the meaning of section 47 of the Trade Disputes Act: there must be a dispute; the dispute must involve a trade; the dispute must be between employers and workers, or between workers themselves; and the dispute must be connected with the employment or non-employment, terms of employment, or physical conditions of work of any person. ${ }^{64}$ The court went on to declare that: "In the light of the principles above explored I really cannot make a finding in favour of the Appellants [ie the NLC]. In resolving these issues, I am satisfied that what the Appellants did and sought to do were not in line with a trade dispute properly so called."65

In so holding, the court upheld the corresponding aspect of the Ukeje decision. However, this aspect of the court's reasoning is much too cursory and far too unsystematic to provide much insight into the logic that underpins it. For one, the court devoted barely two double-spaced pages to its own reasoning concerning this pivotal and highly consequential aspect of its decision (much of which was in any case taken up by a paraphrase of the relevant legislative provision). The court offered no analysis at all of the elements of the definition of a trade dispute on which it relied. These elements were simply reproduced from the relevant legislation. The court made no attempt systematically and carefully to relate this definition to the facts of the case. The reader is thus left in the dark as to what exactly it is about the NLC's fuel pricing dispute with the government that disqualifies

62 Adams Oshiomhole and Another $v$ Federal Government of Nigeria and Another, suit no CA/A/164/M/04 (18 December 2006) Court of Appeal, Abuja, per Mary Peter-Odili JCA with Bode Rhodes-Vivour JCA and Oyebisi Omoleye JCA concurring (certified true copy on file with the author).

63 Id at 9.

64 Id at 20.

65 Ibid. 
it from meeting the definition of a trade dispute. Exactly which element(s) of the definition of a trade dispute does the fuel pricing dispute not satisfy and why? Important as this discussion is for crafting a convincing argument in the present regard, the decision provides almost no illumination whatsoever in that respect. It is mainly for these reasons that this aspect of the court's reasoning is singularly disappointing and unconvincing. In its palpable weakness, the court's attempt at argumentation departs significantly from the high quality of reasoning that defines the judicial craft of Nigeria's appellate courts.

Concerning the question whether the NLC can declare a strike in its own name, the court had little if anything clear to say. After spending four pages setting out the arguments made in the present connection by counsel for both sides, ${ }^{66}$ the court devoted a mere half page to arguing that, although this and some other issues were not raised by the parties themselves in the lower court, and were in fact raised suo motu [on its own motion] by that court (and without hearing from either counsel), the prevailing law in Nigeria was that, where such an error did not occasion a miscarriage of justice, as in this case, that error would not have a fatal effect on the relevant decision. ${ }^{67}$ Thus, the court spent very little, if any, time addressing systematically the underlying substantive issue (ie whether or not the NLC can declare and prosecute a strike in its own name). It can be assumed, however, that, because the court did not set aside the corresponding portions of the Ukeje decision, it upheld the lower court's reasoning on this specific question. Yet, given the importance of that question in Nigeria's socio-economic and political context, the court's failure explicitly to raise, examine, reason and pronounce on that question is very disappointing.

With respect to the question whether the NLC and its allies can undertake anti-fuel price hike mass action campaigns (as opposed to strikes), the court reasoned that, since no provision (or element thereof) in the Constitution is superior to any other (except where explicitly provided), the NLC's right to freedom of assembly and freedom of expression cannot override its obligations not to exercise those freedoms at the expense of the public good and contrary to the peace and order of society. ${ }^{68}$ As such, in the court's view, "since the Appellants are using a trade dispute to defend their action [sic] and the proposed strike they must do so within the definition of a trade dispute as envisaged by the Trade Disputes Act, Laws of the Federation of Nigeria, 1990." ${ }^{69}$ The court then concluded that the NLC cannot undertake mass actions in protest against fuel price strikes. In its own words:

“... there is little to say other than that what the Appellants set out for [sic] like calling out market women and school children and directing that all vehicular

66 Id at 9-12.

67 Id at 13.

68 Id at 24 .

69 Ibid. 
movements cease including all airlines shut down [sic] are certainly not what the Act provided for or envisaged, since one cannot put these other persons within the employment covered by the trade unions being used [sic]."70

Here again, the court's reasoning is rather too cursory, loosely articulated and unsystematic to be convincing. For one thing, the court's reasoning regarding the arguments put before it which were founded on the Constitution and based on the African Charter (ie concerning the rights of NLC members to protest individually or collectively, under the NLC's auspices and banner, against any government action that they disagree with) is superficial at best. ${ }^{71}$ Despite their centrality to the question at hand, the court analysed neither section 39 of the Constitution nor the relevant provisions of the African Charter Act to any significant extent. Furthermore, although relied upon extensively by counsel to the NLC and discussed (though all too briefly) in the court's judgment, there is no detailed or systematic analysis of the elements of, and exceptions to, section 40 of the Constitution. Not a single one of the hundreds of relevant domestic and international cases which outline the elements of, and exceptions to, the rights to freedom of association and assembly under section 40 is canvassed and analysed. The reader is not told exactly what principles or rules distinguish the lawful and unlawful prohibition of the exercise of expressive and assembly / associational rights. When exactly does the "public good" or "public order" trump the enjoyment of these rights? A search of this judgment for illumination of these weighty conceptual problems will definitely end in serious disappointment. In any case, in holding that the Trade Disputes Act bars the NLC from "calling out market women and school children", the court conflates and confuses strikes and mass actions. ${ }^{72}$ As was shown in the previous section of this article, while they can occur simultaneously, mass actions and strikes are not one and the same thing. The protest-based act of calling out non-members of the NLC (including market women and students) to join the NLC in a protest action is a form of mass action, the legality of which is not necessarily founded on the declaration of a strike under the Trade Disputes Act. The Constitution clearly does not bar peaceful mass actions generally, however inconvenient they may be for the government of the day. ${ }^{73}$ It is the court's conflation of strikes and mass actions that led it to err in this aspect of its judgment.

Regarding the twin questions of whether or not the NLC can either coerce or persuade non-members to participate in its mass actions, the court also fell into

\footnotetext{
70 Id at 25.

71 Id at 21-25.

72 Id at 25.

73 See the recent Court of Appeal decision on the Public Order Act. The official report of this decision is as yet unavailable, but it was widely reported in the Nigerian media. See "Appeal Court quashes Public Order Act" (12 December 2007) The Punch, available at: <http://www.punchng.com/Articl.aspx?theartic=Art20071212315193> (last accessed 5 July 2008).
} 
error. As noted above, the court explicitly held that the NLC and its allies cannot persuade (or in its words "call out") non-members, such as market women, to participate in its strikes and / or mass actions. It is of course wrong on this question. However, despite its error on the "persuasion question", the court was correct to suggest (albeit in a less than well-reasoned way) that the NLC and its allies cannot coercively force non-members to put an end to all vehicular and air traffic in the country during its strikes or mass actions.

Aside from its disappointing tendency to cursory and superficial reasoning, and the errors and lack of legal logic in too many of its conclusions, the Odili decision may also be critically viewed by many as having either consciously or unconsciously functioned as an important resource for the protection of the interests of the government and of the tiny elite class who benefited from the controversial fuel price hikes. Thus, whatever the real intentions of the judges who authored it, reasonable people may regard the decision as having, in effect, boosted the perceived legitimacy of the government's attempts to repress the pro-poor resistance mounted by the Movement against the government's fuel pricing policy. To hold that the NLC could no longer prosecute its anti-fuel price hike strikes was one thing. However, to go even further to declare that the NLC could not also undertake a peaceful mass action in protest against such price increases was tantamount to an attempt to cripple the Movement entirely. For the Movement's effectiveness depended heavily on the leverage accruing from its success at the mass mobilization of ordinary Nigerians. Thus, like the Ukeje decision, the main effect of this judgment (however unintended) was to deliver an added boost to the government's hitherto greatly weakened capacity to implement its fuel pricing policy. This decision was therefore as steeped as the Ukeje decision in the fuel pricing politics of the day: politics on which it in turn exerted a significant (if ultimately more limited) effect.

\section{A pro-Movement case}

\section{The Gumi decision 74}

On 13 January 2004, the government filed a suit at the Abuja High Court aiming, as it did in the two cases discussed above, to secure a judicial order that would repress the Labour-led anti-fuel price hike Movement. ${ }^{75}$ It sought declarations that "the mass protests and strikes, or any other form or manner of protest as the defendants [ie the NLC] decided or may decide to embark upon ... is illegal, unlawful and is contrary to peace and order of the nation"76

74 Federal Government of Nigeria and Another $v$ Adams Oshiomhole and Another, suit no FCT/HC/CV/350/2004 (16 January 2004) High Court of the Federal Capital Territory, Abuja, per LH Gumi CJ (2004) 9 Weekly Reports of Nigeria 129.

75 While the Abuja High Court ranks at the same level in the judicial hierarchy as the Federal High Court which issued the Ukeje decision, it ranks lower than the Court of Appeal which delivered the Odili decision.

76 Gumi decision, above at note 74 at 130 (emphasis added). 
and that the NLC is not "entitled to embark on any protests or strikes in respect of any matter not within the preview [read "purview"] of the Trade Union and Trade Disputes Acts Caps 437 and 432 respectively of the Laws of the Federation of Nigeria 1990". ${ }^{77}$ The government also sought an injunction restraining the NLC from embarking on "any mass protest and / or strikes or any form or manner of protest on $21 / 1 / 04$ or at any time thereafter". ${ }^{78}$ Due to the urgency of the matter, the government also requested that, pending the hearing of the main suit, the court should issue an interlocutory injunction barring the NLC from prosecuting a strike and / or mass protest on 21 January 2004. It is with this interlocutory application that we are concerned, for the main suit was later abandoned by the government and was never adjudicated.

In essence, and quite remarkably for a supposedly democratic regime, what the government had asked the court to do in this case was to bar the NLC from launching strikes or any other form of protest (peaceful or otherwise) against its fuel pricing policy, for an indefinite period of time. In the government's view, not only did the NLC not have the right to strike over this policy (as fuel prices supposedly do not affect the terms of employment of NLC members), but that body also did not have the constitutional right to protest against this policy in any other way. Clearly therefore, this suit was an integral part of the government's strategy of repressing a struggle that, as was shown in the second section of this article, had been extremely effective at obstructing, or at least slowing down considerably, the government's determined attempts to raise fuel prices in Nigeria to so-called international levels. The government's justification for requesting so seemingly harsh a court ruling was that, in its view, such mass protests and strikes "severely disrupt public life and [inflict] hardship and suffering on Nigerians and non-Nigerians alike" and "inflict colossal and irreparable financial loss on the nation, all corporate bodies and establishments as well as individuals". ${ }^{79}$

For its part, the NLC argued that there was an unresolved trade dispute between it and the government and that it, in any case, had "the fundamental right to freedom of expression [under section 39 of the Constitution] which includes the right to protest against unpopular government policies". ${ }^{80}$ Counsel for the NLC also relied on the rights of NLC members to freedom of assembly / association under section 40 of the Constitution. ${ }^{81}$ This line of argument was, of course, very similar to that relied upon by the NLC in its arguments before Justice Ukeje.

The main issue before the court in the interlocutory application was whether the government was entitled to the grant of the injunction it sought

\footnotetext{
77 Ibid.

78 Ibid.

79 Id at 134 .

80 Id at 135.

81 Id at 137.
} 
from the court. To be so entitled, the government had to show that it had a legal right to defend in the main suit, that there was a serious legal question to be determined in that suit, that damages would be inadequate to compensate it if the interim injunction it sought was not granted and it eventually succeeded in the main suit, and that the balance of convenience was in its favour. ${ }^{82}$ In order to determine the first issue (whether the government had a legal right to defend in the main suit), the court had to resolve the following questions: (a) whether the NLC could lawfully undertake mass actions over the government's fuel price hikes; and / or (b) whether it could lawfully prosecute strikes over the same issue. It is the court's reasoning and decisions on these two issues that are of primary concern here.

Concerning the NLC's constitutional right to undertake mass actions in protest at the government's fuel price hikes, the court found against the government and held that, like all other Nigerians, NLC members enjoyed a constitutional right to gather freely and protest jointly against any government policy that might, in their view, affect them adversely. In the court's own words:

\begin{abstract}
"[Section 40 of the Constitution] ... has clearly entrenched the right of assembly of all persons in Nigeria to associate with others and to form associations for the protection of their interest. The word 'interests' has not been clearly defined but I dare say that it cannot be limited to only matters regulating the terms and conditions of employment of workers as stipulated in the Trade Unions Act ... I am of the view that the section confers a right on all Nigerians to meet and discuss all matters on which they may have common interests. If the [sic] Nigerian workers through the Nigerian Labour Congress consider the imposition of the $\mathrm{N} 1.50 \mathrm{k}$ fuel sales tax inimical to their interest, they have a fundamental right to assemble or mass protest in opposition to such imposition. I must however point out that such a right cannot be absolute, for as Mr Falana [counsel to the NLC] said, the right of workers to assemble is subject to the consequences prescribed in the Criminal Laws of the State. If any one violates the law in the process of such protests, the Criminal Laws are there to take care of him [or her]." 83
\end{abstract}

The court then went on to note that any derogation from the rights of workers and other Nigerians to freedom of association / assembly (whether or not done pursuant to the criminal law) must comply with section 45 of the Constitution. ${ }^{84}$ This means that it must: be done pursuant to a validly enacted law; be in the interests of either defence, public safety, public order, public morals or public health, or for the purpose of protecting the rights and freedoms of other persons; and be reasonably justifiable in a democratic

82 Id at 135-36.

83 Id at 137.

84 Ibid. 
society. ${ }^{85}$ In the end, the court reasoned that, as any valid derogation from the rights of the workers who compose the NLC to freedom of association / assembly had to be pursuant to a law that mandated the government so to derogate, the absence of any such law was, on its own, fatal to the government's argument that the NLC was prohibited from engaging in an anti-fuel price hike mass action. In summary, the court was of the view that the NLC was legally entitled to launch such protests as long as they were peaceful and otherwise respectful of the criminal law.

Regarding the NLC's right to prosecute anti-fuel price hike strikes (not mass actions), the court reasoned that Nigerian law does not bar workers (whether or not associated with the NLC) from striking over issues that concern their "interests", and that not even the Trade Disputes Act should be read to such effect. ${ }^{86}$ In coming to this conclusion, the court implied the existence of a broader constitutionally-grounded right to strike over any issue that affects workers' interests.

On the whole, although the court's reasoning in this case is unassailable, it could have profited from a slightly more detailed canvassing and analysis of the relevant provisions of the Trade Disputes Act and the Constitution, as well as from reference to, and application of, the relevant provisions of the African Charter Act. It is realized, of course, that the court may have felt constrained by the fact that, under the Nigerian law relating to the adjudication of motions for the grant of interlocutory injunctions, it could not really "go into the merits of the substantive case" on which the interlocutory motion was grounded. ${ }^{87}$ Thus, the court might have deferred the more detailed analysis of the legal issues raised in the case, until the main suit itself. Still, it would have been possible for the court to offer the reader a slightly more detailed account of its reasoning without violating the rules that guide the judicial consideration of applications for interlocutory injunctions in Nigeria. Such a detailed analysis would have allowed the court, for example, to articulate more clearly the basis of its argument that even the Trade Disputes Act does not bar the NLC from undertaking anti-fuel price hike strikes.

Thankfully, however, quite unlike the courts in the Ukeje and Odili decisions, this court did not conflate, and thus confuse, the NLC's right to prosecute strikes with its right to undertake mass actions. This much is evident from the court's treatment of the two concepts in its ruling. For example, the court declared at one point in its ruling that "we have not been referred to any law that may justify the banning of workers from engaging in strikes or mass protests over issues concerning the interests of such workers". ${ }^{88} \mathrm{Had}$ the court not tended to distinguish one from the other and had it not dealt with them as two separate phenomena, it would have confused itself and

\footnotetext{
85 Id at $137-38$.

86 Id at $136-38$.

87 Id at 135.

88 Id at 138 (emphasis added).
} 
then fallen inexorably into the same kind of serious error that is evident in the relevant aspects of the Ukeje and Odili decisions.

It is also important to note that, whatever the real intentions of its author, the Gumi decision served as an important legitimizing resource in the hands of the Movement. The decision greatly enhanced the strength and legitimacy of the Movement's argument that it was lawfully entitled to undertake the relevant kinds of strikes and / or mass actions. In this way the decision concomitantly strengthened the Movement's pro-poor resistance and affected the play of politics.

\section{BETWEEN ELITE INTERESTS AND PRO-POOR RESISTANCE}

This section offers a brief overarching socio-legal assessment of the behaviour of the relevant Nigerian courts in relation to the Struggles cases that they dealt with during the period under study. To what extent did the courts favour elite over pro-poor interests, and vice versa?

On the one hand, a reading of the Ukeje and Odili decisions may lead one to conclude that Nigerian courts have tended to side with the government and a tiny elite group. Given the fact that the Movement enjoyed the committed support of the vast majority of Nigerians, support that allowed it to exercise significant leverage over Obasanjo's quasi-democratic government, ${ }^{89}$ it is not difficult to see why the Ukeje case was filed in the first place and why the government fought its appeal to the Odili court so tenaciously. It is also not hard to discern why the pro-government decisions in these two cases were quite important for the successful execution of the government's strategy of suppressing the Movement's Struggles. If, as these two courts held, the hitherto highly effective Movement (which depended so heavily on popularly supported strikes and / or mass action for its considerable political leverage) could no longer launch strikes or mass actions against the government's fuel price hikes, who stood to benefit, and who stood to lose? As has been seen, one pointer to the answers to these questions is the fact that the government felt able to raise fuel prices within two days of the Ukeje ruling: something it had been unable to do for some time before that decision. ${ }^{90}$ Clearly, the government and the tiny elite group that profited from high fuel prices did benefit from the pro-government character of these two cases. In the words of a key government official, the main benefit of the Ukeje decision (and by implication the Odili judgment) was that "the impediments placed on cost recovery of petroleum products have now been vacated". ${ }^{91}$

89 See the discussion in the second section of this article. See also Okafor "The precarious Place", above at note 7 at 82 .

90 Nwaigwe "Fuel hike", above at note 15.

91 "Nigeria raises fuel prices after banning strike" (24 September 2004) Naijanet.com at 1, available at: <http://naijanet.com/news/source/2004/sep/24/1000.html> (last accessed September 2004). 
Yet, the Gumi decision tends to suggest the opposite conclusion about the engagement of the Nigerian courts with the Movement's Struggles. The effects of this case clearly favoured the Movement. It legitimized and strengthened to varying degrees the Movement's argument that it was legally entitled to engage in anti-fuel price hike strike mass actions. At the very least, the case did not strengthen the government's efforts to weaken and repress the relevant Struggles.

Thus, on the whole, the Nigerian judiciary has so far oscillated between providing normative and discursive support for the protection of elite interests (on the one hand) and acting as the virtual ally of the Movement (on the other hand). As such, no solid trend is as yet decipherable. However, in relation to the actual reasoning on the substantive questions with which this article is concerned, the Odili decision is (under the doctrine of judicial precedent) the highest ranking judgment. As such, it may plausibly be argued that, on balance and in respect of the issues that are of relevance to this article, the pro-elite / anti-Movement tendency has so far dominated within the Nigerian judiciary. Yet, a definitive answer to this question must await the emergence of further evidence, perhaps in the form of a Supreme Court decision. However, even a Supreme Court decision that supports the Ukeje and Odili line of cases and favours elite interests may similarly lack legitimacy, as a result of their massive unpopularity with the Nigerian people. The fact that, in practice, the Movement is not currently complying with the Ukeje and Odili decisions, and that the government itself did not seriously seek to rely on those cases during the subsequent anti-fuel price hike strike and mass action in June 2007,92 is perhaps the best evidence of the lack of legitimacy that has attended this line of cases: a deficit that appears to have rendered the legal positions laid down in them virtually irrelevant. ${ }^{93}$

\section{CONCLUSION}

This article has analysed, critiqued and placed in their socio-economic and political context, the three allegorical cases that tell the story of the engagement of the Nigerian courts with the anti-fuel price hike struggles which were prosecuted during the period under study by a highly popular Labour-led movement. After discussing the socio-economic context in which this engagement played out, the article exposed and critiqued the legal reasoning that the relevant courts applied in determining the socio-legal questions that arose in those cases. The article has also attempted to tease out the

92 M Oloja, M Okwe, E Anufuro and Y Lawal "Govt sacks PHCN chiefs" (24 June 2007) The Guardian, available at: <http://www.guardiannewsngr.com/news/article01> (last accessed 24 June 2007).

93 On the massive unpopularity of these decisions (leading to their perceived illegitimacy), see E Onwubiko "Decapitation of Labour and the end of opposition" (24 September 2004) The Guardian at 7, available at: <http://odili.net/news/source/2004/sep/24/31.html> (last accessed 24 September 2004). 
ways in which each of those cases, in effect, either advanced the interests of the government and the tiny elite group that benefited from the fuel price hikes, or functioned to legitimize the Movement's pro-poor resistance against those price increases. In the end, it offered an overall socio-legal assessment of the behaviour of the Nigerian courts when faced with various questions relating to the legality and appropriateness of both the Labour-led Struggles and the government's attempt to repress them.

The first overarching conclusion is that the reasoning in the progovernment line of cases tends to be much more cursory, superficial and riddled with obvious error, than the pro-Movement counterpart. As such, the social and legal reasoning in those cases tends to be much weaker. The other broad conclusion is that, although both pro-elite and pro-poor tendencies can be deciphered in the legal reasoning in the relevant jurisprudence, as a result of the operation of the rules of legal precedent, the pro-government line of reasoning (which outlaws the Labour-led anti-fuel price hike struggle) currently prevails in the realm of pure legal logic, though not in terms of the "living law". In practice, as a result of the massive unpopularity and perceived illegitimacy of the pro-government cases, the pro-poor decision has (despite its formal legal subservience to the pro-government cases) actually governed relations between the government and the Movement. Although technically outlawed, anti-fuel price hike strikes and / or mass actions are still effectively prosecuted from time to time in Nigeria. Given this reality, it is only appropriate to remark in ironic fashion that: the anti-fuel price hike struggle is dead, long live the struggle! 